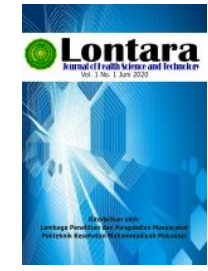

Lontara

Journal of Health Science and Technology

http://jurnal.poltekkesmu.online/lontarariset

Vol 2, No. 2, Desember 2021, pp 113-120

p-ISSN:0000-0000 dan e-ISSN: 2721-6179

DOI: $\underline{\text { https://doi.org/10.53861/lontarariset.v2i2 }}$

\title{
ANALISIS KUALITATIF RESIDU PESTISIDA PADA BAHAN PANGAN DENGAN MENGGUNAKAN METODE KROMATOGRAFI LAPIS TIPIS (KLT)
}

\author{
Muawanah, Nur Qadri Rasyid \\ Teknologi Laboratorium Medis, Politeknik Kesehatan Muhammadiyah Makassar \\ Email: ummi.ahsan79@gmail.com
}

\begin{tabular}{l}
\hline \multicolumn{1}{c}{ Artikel info } \\
\hline Artikel history: \\
Received; 03-09-2021 \\
Revised: 22-10-2021 \\
Accepted; 24-11-2021
\end{tabular}

Keyword:

Residue of pesticide, foodstuffs, Thin Layer Chromatography

\section{Kata Kunci:}

Residu pestisida, bahan pangan, Kromatografi Lapis Tipis

\begin{abstract}
Vegetables and fruits are foodstuffs whose cultivation process requires pesticides. In addition to farmers who apply pesticides, pesticide poisoning can also be experienced by people who consume agricultural products including vegetables through the pesticide residues contained in them, so that it will have a negative impact on human health who consume them continuously. The purpose of the study was to determine the presence of pesticide residues in foodstuffs. This research is a laboratory observation with a simple random sampling technique. In this study, a qualitative analysis of organophosphate and carbamate pesticide residues in food ingredients was carried out using the Thin Layer Chromatography (TLC) method. Based on the results of the study, from 15 (fifteen) samples of vegetables, no organophosphate chlorpyrifos pesticide content was detected, but the carbamate group was detected in samples of spinach, cabbage, and carrots marked with spots and the Rf value was the same as the Furadan standard. Thus, it is hoped that the community will wash the vegetables before they are processed and consumed.
\end{abstract}

\begin{abstract}
Abstrak. Sayuran dan buah-buahan merupakan bahan pangan yang proses penanamannya membutuhkan pestisida. Selain petani yang mengaplikasikan pestida, keracunan pestisida dapat pula dialami oleh masyarakat yang mengkonsumsi hasil pertanian termasuk sayuran melalui residu pestisida yang terkandung di dalamnya, sehingga akan memberikan dampak negatif terhadap kesehatan manusia yang mengonsumsinya secara terus menerus. Tujuan penelitian adalah untuk mengetahui adanya residu pestisida pada bahan pangan. Penelitian ini bersifat observasi laboratorik dengan teknik pengambilan sampel secara simple random sampling. Dalam penelitian ini dilakukan analisis kualitatif residu pestisida organofosfat dan karbamat pada bahan pangan dengan menggunakan metode Kromatografi Lapis Tipis (KLT). Berdasarkan hasil penelitian dari 15 (lima belas) sampel sayur-sayuran tidak terdeteksi adanya kandungan pestisida golongan organofosfat klorpirifos, tetapi untuk golongan karbamat terdeteksi pada 3 (tiga) sampel yaitu kangkung, kol, dan wortel ditandai adanya bercak noda dan nilai Rf yang sama dengan standar Furadan. Diharapkan kepada masyarakat untuk mencuci bersih sayur-sayuran sebelum diproses dan dikonsumsi.
\end{abstract}


Coresponden author:

Email: ummi.ahsan79@gmail.com

artikel dengan akses terbuka dibawah lisensi CC BY -4.0

\section{PENDAHULUAN}

Hama adalah agen utama yang mempengaruhi tanaman utamanya pada bahan pangan sehingga diperlukan berbagai jenis pestisida baik sintesis atau organik untuk mengusir dan mengendalikan penyebarannya. Serangan hama pada berbagai tanaman akan menyebabkan gagal panen karena kerusakan besar saat pra panen dan pasca panen. Telah dipelajari bahwa di negaranegara maju, kerusakannya lebih kecil dibandingkan dengan negara-negara berkembang sehingga produksi bahan pangan meningkat dari hari ke hari. Karena alasan ini, pestisida muncul di pasaran dalam skala besar. Namun, pemakaian skala besar ini berujung pada efek samping yang juga meningkat. Sayuran dan buah-buahan adalah sumber utama makanan manusia. Berbagai jenis unsur hadir dalam sayuran yang menyehatkan manusia. Namun, sayuran dan buah-buahan merupakan bahan pangan yang proses penanamannya membutuhkan pestisida. Penggunaan pestisida untuk mengendalikan jasad pengganggu telah dapat memberikan banyak keuntungan. Penggunaan pestisida (terutama insektisida) dapat menyelamatkan potensi pertanian antara $10.2-17.5 \%$. jumlahnya ini lebih besar lagi pada musim hujan karena serangan hama pada musim ini lebih besar dibandingkan pada saat musim kemarau. Berbagai laporan yang dicatat WHO menunjukkan bahwa di Amerika, Eropa, dan Jepang, kehilangan panen diperkirakan berkisar 10-30\%, sedangkan di negara sedang berkembang jauh lebih tinggi lagi, yaitu 40-75\%. (Ridawati, 2013).

Pestisida mengandung berbagai jenis reagen aktif, sehingga pestisida diklasifikasikan berdasarkan reagen aktifnya. Pereaksi aktif ini memiliki berbagai jenis tindakan pada hama yang tindakannya tidak spesifik untuk hama. Selain itu, beberapa pestisida lebih tahan lama dan berada di lingkungan untuk jangka waktu yang lama sehingga memiliki kemungkinan toksisitas yang lebih besar jika terpapar pada individu yang tidak diinginkan. Mekanisme toksisitas pestisida pada manusia sama seperti pada hama yaitu menyerang pada bagian neurotransmitter hama. Jika makanan yang terkontaminasi pestisida digunakan oleh manusia, maka pestisida ini juga dapat menyerang neurotransmitter manusia dan tidak ada ciri pembeda efek pestisida pada manusia dan hama. (Neff, et.al., 2012)

Departemen Kesehatan Republik Indonesia menyatakan bahwa pestisida yang banyak direkomendasikan untuk bidang pertanian adalah golongan organofosfat karena golongan ini lebih mudah terurai di alam. Golongan organofosfat mempengaruhi fungsi syaraf dengan jalan menghambat kerja enzim kholinesterase, suatu bahan kimia esensial dalam mengantarkan impuls sepanjang serabut syaraf. (Afriyanto, 2008). Selain golongan organofosfat, terdapat juga pestisida golongan karbamat dimana memiliki sifat yang sama dengan organofosfat yaitu menghambat enzim kholinesterase yang 
Analisis Kualitatif Residu Pestisida Pada Bahan Pangan Dengan Menggunakan Metode

Kromatografi Lapis Tipis (KLT)

(Muawanah, Nur Qadri Rasyid)

berperan dalam penerusan rangsangan system syaraf.

Petani yang mengaplikasikan pestida, keracunan pestisida dapat pula dialami oleh masyarakat yang mengkonsumsi hasil pertanian termasuk sayuran melalui residu pestisida yang terkandung di dalamnya. Residu pestisida bersifat akumulatif di dalam tubuh manusia, sehingga akan memberikan dampak negatif terhadap kesehatan manusia yang mengonsumsi sayuran yang mengandung residu pestisida secara terus menerus.

Aplikasi pestisida pada tanaman akan terserap di dalam tanah bersama dengan unsur-unsur yang dibutuhkan oleh tanaman dan air. Melalui jalur yang berbeda, pestisida dapat masuk ke dalam tubuh manusia secara oral, dermal dan melalui inhalasi. efek samping pestisida yang dapat mengganggu kesehatan menjadi hal yang penting untuk mengontrol penggunaan pestisida dalam batas potensial. Indonesia merupakan negara dengan produksi buah dan sayuran yang sangat tinggi menjadikan Indonesia sebagai salah satu dari negara-negara yang menggunakan pestisida dalam jumlah besar untuk meningkatkan produksi bahan pangan utamanya buah dan sayuran. Namun, di negara-negara berkembang termasuk Indonesia beberapa petani kekurangan informasi tentang penggunaan pestisida yang baik.

Saat ini terdapat berbagai metode untuk mengembangkan studi tentang residu pestisida yang berbeda dan pengaruhnya terhadap manusia. Pestisida golongan organofosfat dan karbamat saat ini banyak digunakan sebagai agen pengusir dan pembasmi hama namun, penggunaan yang berlebihan dari kelas ini, menyisakan konsentrasi besar pada sayuran.

Aplikasi kromatografi lapis tipis untuk pemisahan, deteksi pestisida secara kualitatif telah dilakukan dari pertengahan tahun 2000 hingga tahun 2004. Analisis dicakup untuk berbagai sampel, seperti makanan, tanaman, lingkungan dan residu pestisida dari berbagai jenis termasuk golongan organofosfat dan golongan karbamat. (Sherma, 2005).

Berdasarkan penelitian dari enam pasar sayur menggunakan pereaksi etil asetat sebagai larutan ekstraksi. Hasilnya menunjukkan bahwa 79\% sampel terkontaminasi dengan cipermethrin, $70 \%$ dari imidacloprid dan 65\% sampel terkontaminasi oleh klorpirifos. (Munawar, 2013).

Berbagai jenis sayur non organik dipasarkan di kota Makassar, hal ini berpotensi mengandung residu pestisida yang dapat membahayakan Kesehatan konsumen sehingga diperlukan penelitian tentang analisis kualitatif residu pestisida dalam berbagai bahan pangan yang dijual di pasar kota Makassar menggunakan metode Kromatografi Lapis Tipis.

\section{BAHAN DAN METODE}

Jenis penelitian yaitu observasi laboratorik yang bersifat deskriptif dengan teknik pengambilan sampel yaitu simple random sampling dan dilaksanakan di Laboratorium Toksikologi Klinik Politeknik Kesehatan Muhammadiyah Makassar. Populasi adalah semua sayur-sayuran yang diperjualbelikan di Pasar tradisional Kota Makassar, sedangkan sampel yang diteliti sebanyak 15 
sampel sayur yaitu tomat, sawi hijau, sawi putih, kangkung, bayam, kol, kembang kol, brokoli, selada, wortel, seledri, pare, buncis, timun, dan kacang panjang.

Alat-alat yang digunakan adalah Blender, Pipet tetes, Lumpang dan alu, Chamber, Corong pisah, Penangas air, Klem dan statif, Bunsen, Gelas beaker, Timbangan analitik, Erlenmeyer, Tabung sentrifuge, Gelas ukur, Batang pengaduk, Sentrifuge, Rak tabung, Bahan yang digunakan yaitu Aquades, Larutan baku organofosfat (Klorpirifos) dan karbamat (Furadan), Kertas Saring, Iodium, Metanol, Petroleum Eter, N- Hexane, Aseton, Etil Asetat, natrium sulfat anhidrat, plat KLT.

Analisis residu pestisida golongan organofosfat dilakukan dengan menimbang sampel sayur sebanyak $10 \mathrm{~g}$ yang telah dipotong kecil-kecil, kemudian dihancurkan lalu ditambahkan dengan $25 \mathrm{~mL}$ n- heksana dan $25 \mathrm{~mL}$ etil asetat. Kemudian disentrifuge, filtrat dipisahkan melalui corong berisi natrium sulfat anhidrat setebal $2 \mathrm{~cm}$. Ekstrak diuapkan menggunakan penangas air sampai kira-kira sebanyak $10 \mathrm{~mL}$. Sedangkan larutan standar senyawa pestisida organofosfat yaitu klorpirifos ditimbang dengan kadar masing-masing $0,4 \mathrm{mg} / \mathrm{mL}$. Larutan sampel dan standar ditotolkan secara terpisah masing-masing sebanyak $50 \mu l$ dan jarak rambat $12 \mathrm{~cm}$ pada plat KLT dan dimasukkan ke dalam chamber yang berisi eluen yaitu: n-heksan-aseton (9:1). Plat KLT dikeluarkan dan dikeringkan pada suhu kamar, kemudian dilihat bercak noda dengan sinar lampu UV dan dihitung nilai Rf (Retention of Factor).

Untuk analisis residu pestisida golongan karbamat dilakukan dengan menimbang sampel sayur sebanyak $5 \mathrm{~g}$ yang telah dipotong kecil-kecil, kemudian dihancurkan lalu diekstraksi sebanyak dua kali dengan $5 \mathrm{~mL}$ Petroleum Eter dan ekstrak dicuci dengan Petroleum eter. Ekstrak yang diperoleh diuapkan di penangas air sampai kira-kira sebanyak $3 \mathrm{~mL}$. Sedangkan larutan standar senyawa pestisida karbamat yaitu Furadan ditimbang dengan kadar masing-masing 0,4 mg/mL. Larutan sampel dan standar ditotolkan secara terpisah masing-masing sebanyak $50 \mu l$ dan jarak rambat $12 \mathrm{~cm}$ pada plat KLT dan dimasukkan ke dalam chamber yang berisi eluen yaitu: Petroleum eter dan metanol $(25: 1)$. Plat KLT dikeluarkan dan dikeringkan pada suhu kamar, kemudian dilihat bercak noda dengan sinar lampu UV dan dihitung nilai Rf (Retention of Factor). (Rahayu dan Solihat, 2018)

\section{HASIL PENELITIAN}

Penelitian tentang analisis kualitatif residu pestisida pada sampel sayur-sayuran menggunakan metode Kromatografi lapis Tipis (KLT). Hasil pemeriksaan secara kualitatif residu pestisida golongan organofosfat dan karbamat dapat dilihat pada Tabel 1 dan Gambar 1.

Berdasarkan Tabel 1 dan Gambar 1 diperoleh hasil bahwa dari 15 (lima belas) sampel sayursayuran terdapat 3 (tiga) sampel yang positif terdapat pestisida karbamat ditandai dengan adanya bercak noda yang tampak pada sinar lampu UV dan nilai Rf yang sama dengan standar Furadan $(0,41)$ yaitu kangkung $(0,41)$; kol $(0,43)$; dan wortel $(0,40)$, sedangkan pestisida organofosfat tidak terdeteksi. Interpretasi hasil penelitian ini positif yaitu apabila warna bercak noda dan nilai Rf antara sampel dan standar sama. 
Analisis Kualitatif Residu Pestisida Pada Bahan Pangan Dengan Menggunakan Metode

Kromatografi Lapis Tipis (KLT)

(Muawanah, Nur Qadri Rasyid)

Tabel 1. Hasil Analisis Kualitatif Residu Pestisida pada Bahan Pangan dengan Metode Kromatografi Lapis Tipis (KLT)

\begin{tabular}{llccc}
\hline $\mathbf{N o}$ & \multicolumn{1}{c}{ Sampel } & Rf Organofosfat & Rf Karbamat & Keterangan \\
\hline $\mathbf{1}$ & Klorpirifos (Standar & 0,69 & - & Positif \\
& Organofosfat) & - & & \\
\hline $\mathbf{2}$ & Furadan (Standar Karbamat) & - & 0,41 & Positif \\
\hline $\mathbf{3}$ & Tomat & 0,26 & 0,63 & Negatif \\
\hline $\mathbf{4}$ & Sawi Hijau & - & 0,28 & Negatif \\
\hline $\mathbf{5}$ & Sawi Putih & 0,35 & 0,71 & Negatif \\
\hline $\mathbf{6}$ & Kangkung & 0,18 & 0,41 & Positif \\
\hline $\mathbf{7}$ & Bayam & - & 0,66 & Negatif \\
\hline $\mathbf{8}$ & Kol & - & 0,43 & Positif \\
\hline $\mathbf{9}$ & Kembang Kol & - & 0,72 & Negatif \\
\hline $\mathbf{1 0}$ & Brokoli & - & 0,51 & Negatif \\
\hline $\mathbf{1 1}$ & Selada & 0,25 & 0,65 & Negatif \\
\hline $\mathbf{1 2}$ & Wortel & 0,34 & 0,40 & Positif \\
\hline $\mathbf{1 3}$ & Seledri & - & 0,78 & Negatif \\
\hline $\mathbf{1 4}$ & Pare & - & 0,59 & Negatif \\
\hline $\mathbf{1 5}$ & Buncis & - & 0,63 & Negatif \\
\hline $\mathbf{1 6}$ & Timun & - & 0,59 & Negatif \\
\hline $\mathbf{1 7}$ & Kacang Panjang & & 0,15 & Negatif \\
\hline Sum & Data Prmat & & \\
\hline
\end{tabular}

Sumber: Data Primer (2021)

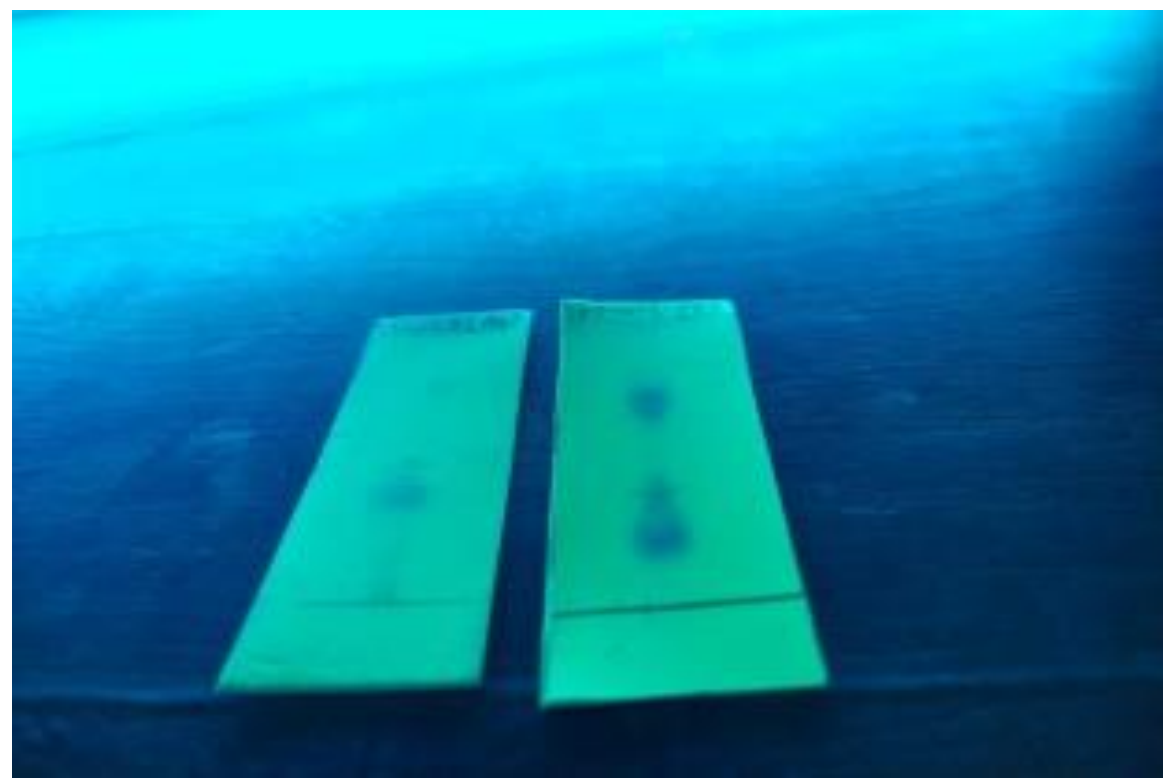

Gambar 1 Warna bercak noda sampel dan standar residu pestisida Karbamat

\section{PEMBAHASAN}

Penelitian ini bertujuan untuk melakukan analisis kualitatif residu pestisida pada bahan pangan dengan menggunakan metode Kromatografi Lapis Tipis (KLT). KLT merupakan suatu metode pemisahan yang terjadi berdasarkan adanya perbedaan kecepatan migrasi analit terhadap dua fase yaitu fase diam dan fase gerak (eluen). Kepolaran dari eluen akan meningkatkan kecepatan migrasi 
analit yang menyebabkan terbentuknya bercak noda dan nilai faktor retensi (Rf) dapat ditentukan (Gandjar dan Rohman, 2007). Adapun jenis residu pestisida yang diteliti adalah golongan organofosfat dengan klorpirifos sebagai standar sedangkan karbamat yaitu furadan.

Dalam ekstraksi sampel sayur-sayuran untuk pemeriksaan pestisida organofosfat digunakan pelarut organik yaitu N-Hexana dan etil asetat karena residu pestisida organofosfat bersifat agak polar sehingga dapat diekstraksi dengan pelarut agak polar yaitu etil asetat. Setelah itu disaring dengan menggunakan penambahan natrium sulfat anhidrat untuk mengikat molekul air yang terdapat pada sayuran. Eluen yang digunakan dalam pemisahan dengan metode KLT untuk residu pestisida organofosfat adalah N-hexana dan aseton (9:1) dimana dengan penambahan pelaru sedikit polar seperti aseton ke dalam pelarut non polar seperti $\mathrm{N}$-hexana akan meningkatkan harga $\mathrm{Rf}$ secara signifikan karena analit mampu berinteraksi lebih kuat dengan fase diam. Selain itu, klorpirifos memilki kelarutan yang cukup baik terhadap aseton. (Marzuki, dkk., 2014)

Ekstraksi sampel sayuran untuk residu pestisida karbamat digunakan pelarut eter karena pelarut tersebut memberikan hasil yang cukup baik dengan perolehan kembali diatas $80 \%$ sehingga memenuhi persyaratan untuk analisa sampel dalam matriks biologis. Dalam hal ini dipilih eluen yaitu eter dan metanol (25:1) yang juga merupakan campuran antara pelarut non polar dengan pelarut non polar. Dengan penggunaan eluen tersebut diperoleh hasil pemisahan komponen analit yang baik dengan harga Rf yang yang memenuhi syarat.

Metode analisis dengan KLT dinyatakan selektif apabila adanya keterpisahan antara dua noda yang terbentuk dimana nilai $\mathrm{Rf}$ yang baik adalah antara 0,2 hingga 0,8.7 Dari hasil penelitian diperoleh nilai $\mathrm{Rf}$ dari standar residu pestisida organofosfat klorpirifos yaitu 0,69 sedangkan furadan untuk standar karbamat sebesar 0,41. Hasil KLT dari sampel sayuran untuk residu pestisida organofosfat dari 15 sampel negatif tidak ada residu pestisida klorpirifos. Sedangkan untuk pestisida karbamat diperoleh hasil bahwa dari 15 sampel sayuran hanya 3 sampel yang memiliki bercak noda dan nilai Rf yang identik bila dibandingkan dengan standar furadan $(0,41)$ yaitu kangkung $(0,41)$, kol $(0,43)$, dan wortel $(0,40)$. Hal ini berarti bahwa 3 sampel sayuran tersebut mengandung residu pestisida karbamat furadan.

Hasil pemeriksaan residu pestisida organofosfat dengan metode KLT dari sampel sayuran terdapat 5 sampel yang menghasilkan bercak noda yang lain yang belum diketahui yang tidak sama dengan standar klorpirifos. Kemungkinan hal tersebut disebabkan oleh penggunaan pelarut agak polar seperti etil asetat dalam ekstraksi sehingga berbagai jenis senyawa atau residu pestisida yang lain dari masing-masing sampel yang ikut terekstraksi bukanlah jenis residu pestisida organofosfat. (Sugijanto, dkk., 2010)

Sedangkan, sebagian besar dari sampel sayuran untuk pemeriksaan residu pestisida organofosfat menunjukkan hasil negatif dengan tidak adanya bercak noda yang dihasilkan karena residu pestisida tersebut bersifat mudah terurai oleh alam maupun yang mengendap dalam tanah. 
Selain itu, residu pestisida lebih mudah larut dalam air bila dibandingkan dengan pestisida karbamat dan organoklorin. (Alegantina, dkk., 2005)

Pestisida organofosfat merupakan golongan pestisida yang banyak digunakan oleh petani, karena memiliki daya basmi yang kuat, cepat, dan pada tanaman terlihat jelas hasilnya. Akan tetapi, sering tidak ditemukan sebagai residu pada sayuran karena golongan pestisida ini pada umumnya larut dalam air sehingga mudah terurai dan hilang dalam proses pencucian. Penelitian ini sejalan dengan penelitian sebelumya, yaitu tidak ditemukannya adanyan kandungan pestisida golongan organofosfat pada sampel sayur dan buah karena diambil di tempat penjualan bukan dari tempat penanaman sehingga sampel tersebut sudah mengalami pencucian berkali-kali. (Sudarma, dkk., 2020)

Pemeriksaan residu pestisida karbamat dengan teknik KLT diperoleh bercak noda dari semua sampel sayuran, tetapi hanya ada 3 sampel yang memiliki noda dan nilai Rf yang sama dengan standar furadan. Hal ini berarti 12 sampel sayuran itu kemungkinan menggunakan jenis pestisida yang lain bukan jenis pestisida karbamat furadan. Penggunaan pelarut metanol sebagai eluen merupakan salah satu faktor yang mempengaruhi karena metanol sebagai pelarut yang bersifat polar sehingga mampu melarutkan berbagai jenis senyawa sehingga residu pestisida atau senyawa endogen yang lain dari masing-masing sampel sayuran yang ikut terpisahkan atau terelusi. (Sugijanto, dkk., 2010)

\section{KESIMPULAN DAN SARAN}

Adapun kesimpulan dari penelitian ini bahwa dari analisis residu pestisida organofosfat dengan standard klorpirifos terhadap 15 sampel sayuran menunjukkan hasil yang negatif, sedangkan untuk residu pestisida karbamat diperoleh hasil 3 (tiga) sampel sayuran yang positif yaitu kangkung (Rf 0,41), kol (Rf 0,43), dan wortel (Rf 0,40) yang sama dengan standar furadan (0,41). Saran untuk peneliti selanjutnya bahwa perlu dilakukan penelitian lanjutan untuk penetapan kadar residu pestisida pada bahan pangan.

\section{UCAPAN TERIMA KASIH}

Terima kasih kepada Direktur, LPPM Politeknik Kesehatan Muhammadiyah Makassar yang telah memberikan izin dan dana penelitian, Ka Prodi dan seluruh civitas akademika prodi TLM serta pihak Laboratorium Toksikologi Klinik Politeknik Kesehatan Muhammadiyah Makassar yang telah memberikan bantuan dan dukungan bagi seluruh rangkaian kegiatan penelitian ini.

\section{DAFTAR PUSTAKA}

Afriyanto. (2008). Kajian Keracunan Pestisida padaPetani Penyemprot Cabe di Desa Candi Kecamatan Bandungan Kabupaten Semarang [Tesis]. Semarang: Universitas Diponegoro.

Alegantina S, Raini M, Lestari P. 2005. Penelitian Kandungan Organofosfat Dalam Tomat dan Selada yang Beredar di Beberapa Pasar di DKI Jakarta. Jurnal Media Litbang Kesehatan. Vol. XVNo. 1. 
Alsuhendra., Ridawati (2013). Bahan Toksik dalam Makanan. Bandung: PT Remaja Rosdakarya.

Gandjar, I.G, dan Rohman, A. 2007. Kimia Farmasi Analitis. Yogyakarta. Pustaka Pelajar

Neff, R. A., Hartle, J. C., Laestadius, L. I., Dolan, K., Rosenthal, A. C., \& Nachman, K. E. (2012). A comparative study of allowable pesticide residue levels on produce in the United States. Globalization and Health. https://doi.org/10.1186/1744-8603-8-2

Marzuki A, Naid T, Risky. 2014. Analisis Residu Klorpirifos pada Sawi Hijau (Brassica Rapa Var. Parachinensis L) Terhadap Parameter Waktu Retensi Metode Kromatografi Gas. Jurnal Ilmiah Farmasi. UNSRAT. vol. 3 No. 4. ISSN. 2302-2493.

Mashithoh, N., Aritonang, E. Y., dan Siagian, A. (2016). Analisis Kandungan Zat Pemanis (Siklamat dan Sakarin) pada Selai Buah Tidak Bermerek yang dijual di beberapa Pasar Tradisional Kota Medan. Medan.

Munawar, A. (2013). Quantification of Pesticide Residues in Vegetables by Different Chromatographic Techniques. Journal of Chromatography \& Separation Techniques. https://doi.org/10.4172/2157-7064.1000200

Rahayu M, dan Solihat, F. 2018. Toksikologi Klinik. Badan Pengembangan dan Pemberdayaan Sumber Daya Manusia dan Kesehatan. Cetakan I. Kemenkes.

Sherma, J. (2005). Thin-layer chromatography of pesticides - A review of applications for 2002-2004. Acta Chromatographica.

Sugijanto, Prihatin, Sugijanto, N.E. 2010. Analisis Pestisda Karbaril dengan Metode KLT Densitometri dalam Matriks Kedelai dan Validasi Meodenya. Berk. Penelitian Hayati: 15 (165-169). Fakultas Farmasi. Universitas Airlangga

Sudarma N, Putri N, Prihatiningsih D, 2020. Identifikasi Residu Pestisida Organofosfat dan Karbamat pada Buah dan Sayur yang Dijual di Pasar Badung Denpasar Bali. Jurnal Kesehatan Terpadu 4(1): 13-17, ISSN: 2549 - 8479. Sekolah Tinggi Ilmu Kesehatan Wira Medika Bali. Bali. 